\title{
Antropofagia Distópica de um País em Crise $^{1}$
}

Dystopic Anthropophagy of a Country in Crisis

\section{Beatriz Azevedo}

Beatriz Azevedo

Doutora em Artes da Cena

Universidade Estadual de Campinas (Unicamp) Artista e pesquisadora www.beatrizazevedo.com

1 Este estudo é parte da pesquisa, em andamento, desenvolvida com apoio da Fundação de Amparo à Pesquisa do Estado de São Paulo (Fapesp).

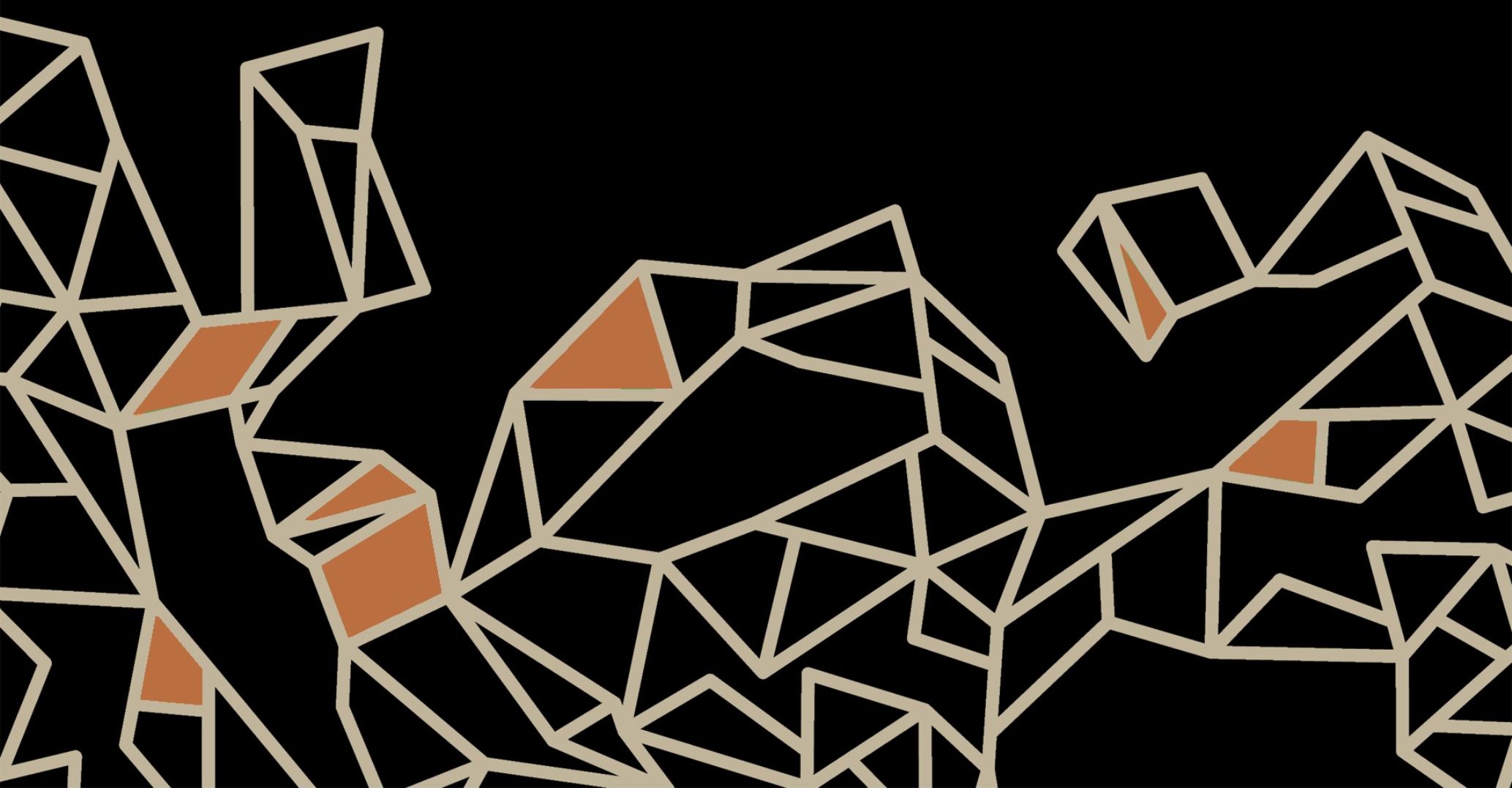




\section{Resumo}

Este é um ensaio sobre antropofagia distópica em um país perpetuamente em crise, partindo da peça teatral $O$ rei da vela, procurando revelá-la enquanto versão "em negativo" das utopias do Manifesto Antropófago de 1928. Expondo a concepção de Oswald de Andrade sobre aquilo que chamou de "baixa antropofagia", este ensaio diferencia a Antropofagia (em sentido ritual como economia simbólica da alteridade) do Canibalismo (em sentido de degradação e exploração capitalista).

Palavras-chave: Antropofagia, Distopia, Oswald de Andrade, O rei da vela.

\section{Abstract}

This is an essay on dystopian anthropophagy in a country in perpetual crisis, starting from the play The candle king, seeking to reveal it as a "negative" version of the utopias of the Manifesto Antropófago of 1928. Exposing Oswald de Andrade's conception of what he called "low anthropophagy", this essay differentiates Anthropophagy (in the ritual sense as symbolic economy of alterity) from Cannibalism (in the sense of capitalist degradation and exploitation).

Keywords: Anthropophagy, Dystopia, Oswald de Andrade, The candle king.

\section{Antropofagia distópica}

Desejo apontar que se nós brasileiros continuarmos indiferentes e amáveis ante os costumes tanto políticos como domésticos que nos distinguem, veremos confirmar-se o calamitoso diagnóstico de que perdemos nossa Cultura sem chegar a ter uma Civilização. (ANDRADE, 1991, p. 1)

Em 1924, Oswald já indicava no seu Manifesto da Poesia Pau-Brasil a preocupação com o que é, ainda hoje, fundamental para o Brasil: "a floresta e a escola". É trágico constatar que, quase um século depois, a floresta já foi destruída e ainda não se completou a escola. No mesmo manifesto, o autor valorizava a arte teatral popular: "Ágil o teatro, filho do saltimbanco. Ágil e ilógico" (p. 6). Em seus primeiros passos na carreira de escritor, Oswald de Andrade escreveu duas peças em francês com Guilherme de Almeida e trabalhou como crítico teatral. No Manifesto Antropófago de 1928, Oswald cita Hamlet 
de Shakespeare no seu célebre Tupi, or not tupi that is the question. Neste aforismo do Manifesto Antropófago, Oswald aglutina em poucos caracteres em apenas oito palavras - uma impressionante densidade de informações e ressignificações. O autor devora, ao mesmo tempo, Hamlet e Shakespeare, referenciais da cultura ocidental, ícones do Renascimento; e os Tupinambá, ameríndios marcadores da resistência durante a colonização.

Aludindo à fala da personagem Hamlet, "to be or not to be, that is the question," que reporta à crise do patriarcado, Oswald substitui a angústia metafísica do príncipe Hamlet, de origem patriarcal, por uma formulação antropofágica, de viés matriarcal, encarnada no sentido não cristão de vingança entre os Tupinambá. A Antropofagia é parte essencial do complexo social da vingança entre os Tupis e, portanto, na tradução filosófica de Oswald, a questão não é mais "ser ou não ser", mas sim "Tupi, or not Tupi". Como sabemos, a Antropofagia é o projeto oswaldiano de recusa dos modelos filosóficos, políticos, estéticos e éticos impostos pelo mundo ocidental - a sua "revolução caraíba" que pretende inverter o vetor colonial.

Em termos do Brasil do século XXI, coloco algumas questões políticas e de sobrevivência das espécies, levantadas pelos questionamentos da antropofagia. Em seu prefácio a meu livro Antropofagia Palimpsesto Se/vagem, publicado pela Cosac Naify em 2016, o antropólogo Eduardo Viveiros de Castro resume o panorama atual:

O mundo não datado nem rubricado com que sonhava Oswald se torna cada vez mais datado - nada mais "datado", mais anacrônico que nosso progressismo crescimentista, em face da baixa antropofagia praticada pelo capitalismo sobre a Terra, que perdeu toda "comunicação com o solo" que não se traduza em lucro - e cada vez mais rubricado, com a gula insaciável dos donos do Brasil em privatizar o que ainda nos resta de território mantido fora do mercado - as terras indígenas, as áreas de proteção ambiental, os territórios quilombolas, todos os regimes tradicionais de territorialização que ainda não foram rubricados pelo latifúndio e o agronegócio. "Será esse o Brasileiro do século XXI?" Ou, quem sabe, a generosa utopia de nossa antropofagia, mundializada como era seu destino e como anunciava Oswald, sobreviva ainda, rexista nas revoltas indígenas na América Latina, nas ocupações "selvagens" urbanas que retomam o espaço público, no ativismo ecopolítico que quer a terra, e a Terra, de volta? Pois como disse Oswald em seu testamento: "Desta terra, nesta terra, para esta terra. E já é tempo". (VIVEIROS DE CASTRO, 2016, p. 19) 
Com isso em mente, este artigo passará pela produção teatral de Oswald de Andrade e se deterá em O rei da vela, desenvolvendo nossa visão de que esse texto pode ser lido como um negativo do Manifesto Antropófago (1928). Apenas cinco anos após a criação do manifesto de 1928, em 1933 o autor viraria do avesso as utopias do Matriarcado de Pindorama para expor a decadência do patriarcado em $O$ rei da vela, seu texto mais corrosivo e distópico.

Se nos anos 1920 os manifestos ocuparam a cena, apenas na década de 1930 o escritor aplicaria com propriedade suas concepções em obras teatrais, escrevendo aquelas que são suas peças "acabadas": A morta, O homem e o cavalo e O rei da vela. Existem ainda outras peças "inacabadas" como o Santeiro do mangue (Mistérios gozozos) e A recusa, além de pequenos fragmentos de cenas, criações de personagens e esboços de roteiros.

Os textos para teatro, escritos na primeira metade do século $X X$, são uma gloriosa exceção no panorama da dramaturgia nacional do período, na maior parte constituída por cópias de fórmulas da comédia de costumes do século XIX. Como afirmou Sábato Magaldi (1967, p. 7), o panorama da dramaturgia no período era formado por "melodramas de mau gosto, como o das pseudoobras metafísicas de Renato Viana ou pela filosofia social do Deus Ihe pague, de Joracy Camargo".

As peças de Oswald foram incompreendidas e rejeitadas em sua época. Flávio de Carvalho tentou encenar O homem e o cavalo no seu Teatro de Experiência, mas a polícia proibiu. Procópio Ferreira chegou a cogitar a montagem de $O$ rei da vela por sua companhia, mas acabou devolvendo-a para Oswald. A recepção por parte dos críticos foi diversificada: Sábato Magaldi em sua primeira leitura acreditou que as peças "seriam incapazes de atravessar a ribalta". Ruggero Jacobbi, ao contrário, afirmou que $O$ rei da vela "manifesta um desembaraço de invenção, uma louca e imprevista beleza que já pertence ao mundo do teatro". Samuel Rawet, espantosamente, escreveu que "Oswald deveria ter trazido para o palco suas preocupações antropofágicas. Se fizesse isso, talvez acordasse em nós a nossa realidade mítica"1. Penso o oposto de Rawet: exatamente no texto teatral $O$ rei da vela as preocupações antropofágicas de Oswald de Andrade aparecem mais bem equacionadas, como veremos.

1 Resenhas críticas ao texto O rei da vela, pesquisa no Acervo Oswald de Andrade, Cedae, Unicamp. 
Neste ensaio, procuro demonstrar que Oswald uniu conceito e forma antropofágicos, apresentando uma visão em negativo do próprio Manifesto Antropófago (ANDRADE, 1928). Ao localizar geograficamente e temporalmente o conflito dramático no Brasil do século XX, o autor deu à Antropofagia uma materialidade: transformou sua teoria cultural e política sobre o colonialismo - o conceito filosófico plural do Matriarcado de Pindorama - em dramaturgia.

O ritual ameríndio da antropofagia serve enquanto metáfora para que o dramaturgo exponha, na São Paulo de 1930, uma "realidade mítica" nacional: o colonialismo. Oswald acredita que "antes dos portugueses descobrirem o Brasil, o Brasil tinha descoberto a felicidade" (ANDRADE, 1928), e é por meio da Antropofagia que ele vê a saída para o impasse do colonialismo.

\section{O rei da vela}

Aqui, os capitais estrangeiros deformaram estranhamente a nossa economia. Dum país que possui a maior reserva de ferro e o mais alto potencial hidráulico, fizeram um país de sobremesa. Café, açúcar, fumo, bananas. Que nos sobrem ao menos as bananas! Os capitais estrangeiros compraram as nossas quedas d'água e criaram um sórdido e meigo urbanismo colonial que passou a ser o que eles queriam - um dos meIhores mercados para os seus produtos e chocalhos. (Andrade, 1931)

Em O rei da vela não vemos Guaraci nem o Bispo Sardinha; as personagens são outras, atualizadas para o contexto brasileiro do século XX: o Americano, o Agiota, o Socialista, o Latifundiário. A peça se passa logo após a quebra da bolsa de valores em 1929 e no início da industrialização. A Crise do Café e o nascimento de uma burguesia urbana nas capitais do país são as circunstâncias que mudaram a fisionomia econômica da nação e servem de pretexto para o desenvolvimento de $\mathrm{O}$ rei da vela. $\mathrm{O}$ autor coloca em cena representantes dos interesses políticos que agitavam a economia nacional àquela época e demonstra as associações que o período produziu. De um lado, vemos o Coronel Belarmino, representante da aristocracia rural, e de outro está Abelardo, dono de uma fábrica de velas e de um escritório de usura. Os contrapontos ideológicos ficam por conta de Abelardo II, o socialista, e de Perdigoto, o fascista. Acima de todos está a personagem do Americano, que a tudo e todos comanda.

Na peça tudo é negociado. O Coronel Belarmino negocia o casamento de sua filha Heloísa com Abelardo I, em uma cooperação mútua em que o burguês 
Abelardo ganha um sobrenome de tradição e em troca concede capital ao fazendeiro que está em decadência econômica devido à crise do café. Perdigoto negocia com Abelardo recursos para a criação de uma milícia fascista que servirá aos dois, fazendeiro e comerciante. O Americano negocia armamentos bélicos em troca de café a preço de banana. Nas primeiras cenas, Abelardo negocia com seus clientes os juros dos empréstimos, quando bate à porta o intelectual Pinote, oferecendo seus serviços de biógrafo de homens ilustres a bom preço.

Para Décio de Almeida Prado (1985, p. 11), "a imagem do Brasil traçada por Oswald era das mais corrosivas. Dentro de nossas fronteiras, o capitalismo regredindo ao estado feudal de que nunca se livrara por completo. No plano internacional, o imperialismo americano agindo como um patrão falsamente bonacheirão". Ou seja, a cruel perspectiva de "um país que vai pra frente", mas não consegue tirar os pés do passado. Importante ressaltar que a crítica de Oswald não se dirige somente ao avanço imperialista, mas sobretudo ataca a permissividade dos grupos industriais nacionais. Escrita na década de 1930, publicada em 1937, e encenada somente em 1967 por Zé Celso Martinez Correa - infelizmente a peça de Oswald de Andrade continua muito atual no Brasil do século XXI. A meu ver, é esta autocrítica que faz de O rei da vela uma pintura tão dilacerante. Oswald afirma, sem papas na língua, que a chave do sucesso burguês é a dependência, ou seja, o "desenvolvimento econômico" que só aconteceu graças aos acordos e barganhas que, no final das contas, levaram o país a uma situação insuportável de submissão e destruição de nossas riquezas naturais. Com desolação, percebemos que, nesse processo, "hipotecamos quedas-dágua, cachoeiras..." (ANDRADE, 2005). Abelardo I diz literalmente que a chave da sua fortuna é uma Chave Yale. Em O rei da vela, Oswald de Andrade explicita as diversas formas de "entregar do ouro ao bandido".

Aparecem em cena todos os setores sociais envolvidos na engrenagem da dependência: como em um desfile, passam a República Velha (oligarquia cafeeira), a burguesia urbana ascendente, a pequena burguesia, o clero, os intelectuais, os militares, os imigrantes, o proletariado urbano e rural, pobres, marginalizados e o capitalismo americano. Uma eterna ciranda que gira sem sair do lugar. O discurso dessas personagens funciona como um manifesto: o importante é traçar em poucas linhas uma caracterização ideológica geral e performática. Nada de profundidades psicológicas ou abstrações existenciais. 
Por meio do humor paródico de Oswald, as personagens configuram-se como "tipos", à moda do Teatro de Revista do começo do século XX. Um dos objetivos do texto é veicular conceitos críticos, em sua maioria inspirados no Marxismo - em releitura antropofágica - de forma simples e direta. Vejamos quais são os principais conceitos e de que maneira eles aparecem na peça:

(1) "A dependência é clássica". Através do romance entre Abelardo e Heloísa, o texto expõe a engrenagem de dependência política e econômica. Heloísa se casaria com Abelardo I, mas quando ele morre, Heloísa se casa com Abelardo II. No entanto, o objetivo do casamento sempre foi colocá-la "à disposição" do Americano.

(2) "Familia é uma cousa distinta, prole é proletariado". Segundo a mentalidade burguesa, família requer propriedade e vice-versa; ao contrário de prole que é caracterizada exatamente pela falta de propriedade. Como Abelardo I diz, "a família e a propriedade são duas garotas que freqüentam a mesma garçonnière quando o pão sobra, mas quando o pão falta, uma sai pela porta e a outra voa pela janela...."

(3) "Freud ignora a luta de classes". Numa conversa, o intelectual Pinote afirma que Freud é subversivo, ao que Abelardo retruca: "só um bocadinho, se não fosse ele nós estávamos muito mais desmascarados. Ele ignora a luta de classes, é uma grande coisa!" (ANDRADE, 1973, p. 79). Esse trecho da peça reafirma a visão de alguns marxistas contra a psicanálise, já que esta seria alienante, pois omite a questão social.

(4) “É a vossa função social." Em O rei da vela, o intelectual quer se vender ao poder e isso serve de pretexto para um dos mais famosos discursos de Abelardo, no qual ele demonstra cruamente o papel do artista numa sociedade capitalista:

Imagine se vocês que escrevem fossem independentes! Seria o dilúvio! A subversão total! O dinheiro só é útil nas mãos dos que não tem talento. Vocês artistas, escritores, precisam ser mantidos pela sociedade na mais pura e permanente miséria! Para servirem como bons lacaios, obedientes e prestimosos. (ANDRADE, 1973, p. 80).

(5) "O preconceito de classe". Totó Fruta do Conde, filho do Coronel Belarmino, é homossexual assumido que encabeça o discurso da "perversão" da 
família, porque diz "não" à imagem do filho perpetuador do nome patriarcal. Mas, apesar disso, é contra a prostituta, defende a virgindade, o machão, e diz, depois de saber que foi traído com uma mulher do Mangue: "onde ficam as convenções, os preconceitos sociais, as diferenças de origem $e$ de classe?" (ANDRADE, 1973, p. 102).

É absolutamente decadente a imagem que o autor desenha da tradicional instituição familiar. Com ironia e deboche, a personagem Abelardo explica o que é a "casa de família": "A casa feita para ter muitos criados, um resto de mucamas e negras velhas lembrando o tronco. $E$ um grande quarto feito para dois seres que se traem e se detestam dormindo na mesma cama e orando no mesmo oratório" (ANDRADE, 1973, p. 116). Sem papas na língua, o burguês Abelardo revela a hipocrisia que cerca a honra de um nome familiar. Oswald de Andrade ataca um dos maiores tabus da sociedade brasileira ou de qualquer país eminentemente católico. Esse era um dos alvos do escritor em O rei da vela - revelar as hipocrisias da burguesia. Segundo Décio de Almeida Prado (1987, p. 223), "ele nunca aceitou a solução burguesa da esposa oficial e permanente ao lado das amantes clandestinas. Oswald teve muitos defeitos, mas não o defeito por excelência burguês: a hipocrisia".

A questão da sexualidade foi amplamente discutida por Mário Chamie em seu artigo "A vela do pan-sexualismo" (1976). Chamie argumenta que a representação orgânica que Oswald encontrou para seu ideal de libertação anárquica foi o ato sexual livre e desinibido. Ele afirma que "o aspecto taurino e dionisíaco do sexo parecia significar para Oswald o início de uma desmistificação de toda ética congelada por interesses de casta e preconceitos de classes" (CHAMIE, 1976, p. 16).

Talvez por isso o próprio título da peça forneça um elemento fálico. É fácil perceber que a vela funciona como uma síntese linguística dos conteúdos da peça. Uma das associações que faço é com o subdesenvolvimento, com a falta de luz elétrica: a vela indica uma regressão ao período colonial; Abelardo é o rei, mas é destruído pelo próprio sistema e a vela passa a significar enterro, morte. Culturalmente, a vela também nos remete à tradição religiosa, às superstições e à ideia do povo em procissão.

Em suma, a peça $O$ rei da vela de Oswald de Andrade trata das profundas transformações que abalaram o Brasil na primeira metade do século $X X$ 
socialmente, economicamente e filosoficamente. $O$ centro de transações econômicas se desloca da área rural para a cidade; o forte da produção brasileira não estará apenas no cultivo agrícola, mas também na produção industrial. Os antigos detentores do poder econômico passam a depender dos novos manipuladores do capital, a burguesia urbana, e o poder político nacional fica cada vez mais atrelado e dependente das decisões das potências do Primeiro Mundo. Oswald traça um painel crítico daquele momento histórico propondo reflexões sobre o nosso passado e sobre os erros de um mecanismo que se repete ciclicamente. $O$ rei da vela acende um flash que ilumina os principais tabus econômicos, culturais e políticos da sociedade brasileira dos últimos séculos.

A meu ver, o texto $O$ rei da vela é também um manifesto de Oswald de Andrade, dessa vez elaborado com as ferramentas da linguagem teatral. Assim, o primeiro aforismo do Manifesto Antropófago (1928, p. 6): "Só a antropofagia nos une. Socialmente. Economicamente. Filosoficamente," aparece "em negativo" em sua dramaturgia. Ou seja, O rei da vela mostra exatamente o oposto do que sonhava a utopia oswaldiana no Manifesto Antropófago, no qual a antropofagia nos uniria na perspectiva ameríndia da sociedade contra o Estado. Oswald realiza cenicamente essa inversão das utopias, em um texto teatral absolutamente distópico.

Ao optar pela crítica ao poder por meio da configuração de tipos (o Burguês, o Fascista, o Latifundiário, o Socialista), a informação visual torna-se de suma importância, pois tem a capacidade de sintetizar iconicamente o código que se quer comunicar. Nessa perspectiva, o autor se utilizou largamente da técnica do desfile que, advindo da festa do Carnaval, consegue expor num curto espaço de tempo o painel das alegorias que constituem uma ala social. Observo que a feição de "desfile" também é próxima da estrutura do próprio Manifesto Antropófago, onde as entidades "desfilam," entrando e saindo de cena a cada aforismo. Vejamos, por exemplo, como se dá a abertura do segundo ato:

\footnotetext{
Pela escada surgem primeiramente, em franca camaradagem sexual, Heloísa e o Americano. Saem pela direita. Depois, Totó Fruta-do-Conde, tétrico. Sai. Em seguida, Dona Poloca, e João dos Divãs. Saem. Depois o velho Coronel Belarmino, fumando um mata-rato de palha e vestido rigorosamente de golfe. Sai. Segue-se-Ihe um par cheio de vida: Dona Cesarina abanando um leque enorme de plumas em maiô de Copacabana e Abelardo I com calças cor-de-ovo e camiseta esportiva. (ANDRADE, 1973, p. 87).
} 
A estrutura de $O$ rei da vela é circular. Na última cena, depois que Abelardo I morre, Heloísa casa-se com Abelardo II, que assume o posto do seu antigo patrão. Ou seja, só mudam os Abelardos, mas tudo se repete ciclicamente e a peça poderia começar de novo, desta vez com Abelardo II e Abelardo III.

Ao escrever $O$ rei da vela, Oswald passava por um período financeiramente difícil, época em que a família Andrade perdeu tudo com a quebra da bolsa de Nova York. Nessa circunstância, o escritor acordava cedo, pegava seu filho pelo braço e percorria os escritórios de agiotagem de São Paulo (MAGALDI, 2004, p. 90). O Agiota Abelardo I é uma elaboração de três agiotas com os quais Oswald lidava diariamente. No livro Dia seguinte e outros dias, Oswald de Andrade Filho conta de onde veio a ideia do cenário do primeiro ato: "O divã futurista estava presente em quase todos esses antros. Telefone, mostruário e outros elementos que Oswald aproveitou existem de fato em diversos desses escritórios" (MAGALDI, 2004, p. 90). As personagens também foram inspiradas em conhecidos de Oswald. O Coronel Belarmino é uma paródia de José Estanislau do Amaral, pai da pintora Tarsila do Amaral, com quem Oswald foi casado; Joana João dos Divãs é uma caricatura de Dulce, filha também de Tarsila que, apesar da beleza, era uma menina "esportiva e gostava de boxe." No entanto, não se pode dizer que $\mathrm{O}$ rei da vela acompanhe os traços de uma estética realista, pois o autor efetua diversas deformações, em situações como aquela em que Abelardo II maneja um chicote para disciplinar os clientes inquietos ou quando, no final da peça, Abelardo II "puxou o tapete" de Abelardo I, que aparece literalmente sentado numa cadeira de rodas. Ou seja, não é por meio de uma fidelidade irrestrita à realidade que o dramaturgo faz a sua crítica, mas exatamente por meio do exagero e da ampliação distorcida. Chamarei de "expressionismo antropofágico" esse traço peculiar que faz com que Oswald de Andrade leve suas ideias a uma literalidade clownesca. No entanto, ele coloca a gargalhada na frente do espanto, inspira-se mais no palhaço Piolin do que no pintor Edward Munch. O possível "expressionismo" de O rei da vela, ao contrário do expressionismo europeu, é antropofágico e choca com humor, espantando mais pelo ridículo que pelo patético explorado pela vanguarda expressionista alemã, por exemplo.

Importante fazer essa diferenciação, pois seguidas gerações de críticos ficaram contentes em detectar na peça de Oswald de Andrade elementos das 
vanguardas europeias, como se isso pudesse dar um atestado de "modernidade" ao nosso escritor. O que é mais importante é exatamente ver como Oswald recriou antropofagicamente todo tipo de informação de que ele dispôs, desde as ideias de Vsevolod Emilevitch Meyerhold até inspirações de Alfred Jarry ou Vladimir Maiakovski. É o caso de pensar também em Bertolt Brecht, dramaturgo alemão que, ao que tudo indica, Oswald não leu antes de escrever $O$ rei da vela - já que àquela época Brecht não era muito conhecido nem na França - e ainda assim observo alguns pontos em comum nas obras dos dois escritores. David George (1985, p. 41) aponta possíveis elos entre Brecht e Oswald: "O teatro como instituição didático-moral/ técnicas anti-ilusionistas/ conceitos marxistas elementares/ paródia clássica/ e parábolas exemplares".

Parodia clássica é o que Brecht fez, por exemplo, com a Ópera dos três vinténs e Oswald realizou com Abelardo e Heloísa. No caso das parábolas exemplares, lembro também de Aquele que diz sim, aquele que diz não do poeta alemão, e da Parábola de Jujuba, que aparece em O rei da vela. Com relação à parodia de Abelardo e Heloísa, o que se desmitifica não é a obra clássica em si, mas o uso que se faz dela. É por isso que a sua ação é a de devorar o mito do amor eterno e transformá-lo num casamento por conveniência. Outro exemplo devorado em $O$ rei da vela é a reprodução de Mona Lisa no escritório de usura de Abelardo. Aqui a crítica se dá para o mercado capitalista da arte e para aqueles que valorizam uma obra pelo status, caso típico de Abelardos e novos ricos em geral. É o uso e a manipulação burguesa da arte que estão em questão, e não propriamente o quadro de Da Vinci ou o Romance Medieval de Abelardo e Heloísa.

Em $O$ rei da vela, o inconsciente das personagens está à flor da pele, elas agem instintivamente: colocam seres humanos dentro de jaulas, estalam chicotes, chupam sorvetes fálicos, sonham com milícias fascistas e outras barbaridades do gênero. Os anti-heróis que desfilam pela peça de Oswald de Andrade têm suas falhas tragicômicas:

(1) Abelardo I é rei, mas morre vencido com uma vela na mão;

(2) Abelardo II é socialista, mas tudo que quer é tomar o lugar do capitalista;

(3) Coronel Belarmino não tem o poder dos antigos coronéis; está falido e humilhado;

(4) Dona Cesarina é a sogra, que ao invés de ser antipática com o genro, Ihe dá a maior bola;

(5) Pinote é o intelectual que só produz literatura para servir à classe dominante. 
Estes anti-heróis têm os nomes que merecem; Oswald se utiliza de trocadilhos e referências para expor a situação da personagem. Com o intelectual Pinote, a língua ferina de Oswald queria atacar o escritor Menotti Del Picchia, que ele chamava de "Pinote Del Micchia." Para ganhar dinheiro, Abelardo recomenda: Pinote não deveria se dedicar à literatura de fricção. No segundo ato, Abelardo chama a respeitável Tia Polaquinha, numa alusão às putas estrangeiras, "Polacas," que vinham para o Brasil no final do século XIX. Na boca de Oswald, Tristão de Athayde vira Cristiano de Bensaude ou até Tristinho do Ataúde. Os trocadilhos atingem até o próprio título da peça: quando Abelardo I agoniza, ela deixa de ser o rei da vela e passa a ser chamado de "o rei da vala". No caso da família aristocrática do Coronel Belarmino, não bastam alguns trocadilhos com os nomes dos filhos, da esposa e da tia. É preciso que todos, sem exceção, "pequem pelo excesso." Nenhum deles é "normal," ninguém está dentro dos padrões de comportamento "aceitáveis" pela sociedade. Um é bêbado, três são homossexuais e duas são taradas... É o exagero agindo para frisar a ideia de decadência da velha e tradicional família aristocrática. A técnica de que o autor se utiliza aqui é a concentração, a mesma que mais tarde utilizará para compor o quadro do céu em $O$ homem e o cavalo. Essa desmoralização radical da família brasileira acontece no segundo ato, o ato da "franca camaradagem sexual," como diz Oswald.

O rei da vela é, em muitos momentos, uma experiência de metateatro, uma espécie de "renovação tropical" do conceito de Bertolt Brecht popularizado com o nome de "distanciamento". O distanciamento se utiliza de algumas técnicas anti-ilusionistas, das quais Oswald também se serve. Ele acaba fazendo, ao lado da crítica à burguesia, uma crítica feroz ao teatro burguês, ao teatro passadista e moralista. Abaixo exemplifico os momentos em que no texto aparecem tais recursos de metalinguagem:

Abelardo I - Não faça entrar mais ninguém hoje, Abelardo.

Abelardo II - A jaula está cheia, seu Abelardo.

Abelardo I - Mas esta cena basta para nos identificar perante o publico. Não preciso mais falar com nenhum dos meus clientes. São todos iguais.

Abelardo I - [...] Comprar os velhos brasões, isso até parece teatro do século XIX. Mas no Brasil ainda é novo.

Abelardo II - Se é. A burguesia só produziu um teatro de classe. Hoje evoluímos. Chegamos à espinafração. 
Abelardo I - Diga-me uma coisa, seu Abelardo. Você é socialista?

Abelardo II - Sou o primeiro socialista que aparece no Teatro Brasileiro.

Abelardo I - E o que é que você quer?

Abelardo II- Sucedê-lo nessa mesa.

Abelardo I - [...] Os degraus do crime que desci corajosamente. Sob o silêncio comprado dos jornais e a cegueira da justiça de minha classe. $O$ contrabando e a pilhagem... Todo o arsenal do teatro moralista de nossos avós. Nada disso me impressiona, nem impressiona mais o público.

Heloísa - O Americano não quer casar...

Abelardo I - Mas o outro casa. É um ladrão de Comédia antiga... Com todos os resíduos do velho teatro. Quando te digo que estamos num país atrasado...

Heloísa - Abelardo, não faça essa loucura. Vamos recomeçar...

Abelardo I - Recomeçar... Uma choupana lírica. Como no tempo do Romantismo. As soluções fora da vida, as soluções no teatro. Para tapear. Nunca. Só tenho uma solução. Sou um personagem do meu tempo, vulgar, mas lógico. Vou até o fim. O meu fim. A morte no $3^{\circ}$ ato. (Grita para dentro) Olá! Maquinista! Feche o pano. (ANDRADE, 1973, p. 113).

Essas ousadias metalinguísticas vão até o momento ápice em que Abelardo resolve conversar com o Ponto, figura emblemática do "velho teatro" que tinha a função de "soprar" o texto para os astros que não se davam ao trabaIho de decorar sua fala.

Abelardo I - (oferece revólver ao ponto e fala com ele) Por favor, seu Cireneu... Vê se afasta de mim esse fósforo...

O Ponto - Não é mais possível.

Abelardo I - Como? Não é possível? O autor não ligaria... (ANDRADE, 1973. p. 114).

A capacidade de síntese e visualização cênica de Oswald de Andrade em muito contribui para a teatralidade de $O$ rei da vela. Veremos como o autor materializou conteúdos nas descrições de cenários e figurinos, fazendo destes elementos expressivos. No cenário do primeiro ato vemos "um retrato da Gioconda, um divã futurista, uma secretária Luis XV e um castiçal de latão" (ANDRADE, 1973. p. 63), tudo no escritório de usura de Abelardo \& Abelardo. Fica clara a necessidade de ostentação de status intelectual (Gioconda), de avanço e modernidade (o divã futurista), de tradicionalismo (a secretária Luis XV) e de atraso colonial (o 
castiçal de latão). É do choque dos gostos estéticos que se compõe a aparência de Abelardo I, e é significativa que essa decoração esteja no escritório de usura, pois é essa a mentalidade burguesa, a de usura em relação à criação artística. A ambientação deste ato é, ao mesmo tempo, expressionista e circense, destacando-se a jaula onde ficam os clientes e o figurino de Abelardo II: "Veste botas e um completo de domador de feras. Usa pastinha e enormes bigodes retorcidos. Monóculo. Um revólver à cinta" (ANDRADE, 1973l, p. 65). Abelardo Il é um misto de domador de circo e socialista à caráter. Heloísa de Lesbos está "vestida de homem" e o cliente vem de "chapéu na mão, uma gravata de corda no pescoço magro" (ANDRADE, 1973, p. 65). Está, literalmente, com a corda no pescoço.

No segundo ato, a contradição cultural fica por conta do cenário que combina móveis mecânicos com pássaros exóticos numa ilha paradisíaca na Guanabara, com a bandeira americana no mastro. Oswald de Andrade brinca com o clichê de se mostrar o Brasil como um paraíso tropical e, nessa descrição de cenário, faz a crítica da "macumba para turista" ou do "samba para inglês ver". O figurino aponta que "as personagens se vestem pela mais furiosa fantasia burguesa e equatorial. Morenas seminuas. Homens esportivos, hermafroditas, menopausas". (ANDRADE, 1973, p. 87). Comicamente, o coronel Belarmino aparece "vestido rigorosamente de golfe" e sua esposa Dona Cesarina veste "maiô de Copacabana e leque enorme de plumas" (ANDRADE, 1973, p. 87).

No terceiro ato, quando Abelardo I vai morrer por culpa da traição do pseudossocialista Abelardo II, este já tirou os bigodes de domador, deixou o monóculo, está "exageradamente vestido de ladrão e é um gentleman" (ANDRADE, 1973, p. 114). O gentleman que ficará com os negócios e a noiva de Abelardo I. Para ele, só resta um cenário composto de ferro-velho de uma casa de saúde, macas e cadeira de rodas. A somatória estética de $O$ rei da vela abusa do "mau gosto" no choque proposital de estilos. A composição resulta em um manifesto semiótico, uma colagem de referências e interferências culturais que convivem num mesmo país em crise. A peça é a tragicomédia patética da perpétua crise brasileira.

Com relação à liberdade de invenção e ao avanço estético que seus textos para teatro representaram, o autor se mostrava consciente de suas contribuições, e tinha a crença de que "o teatro deve esclarecer pela invenção de efeitos, pela indumentária, pela síntese" (ANDRADE, [193?]). Oswald exemplifica sua teoria antinaturalista ao afirmar que: 
O teatro procura obter uma equivalência de fatos e não a sua cópia minuciosa e igual. Se um empregado de escritório de usura aparece no Rei da Vela fantasiado de domador de feras, isso explica bem sua função de todos os dias na vida. Os clientes são vistos numa jaula enfurecida porque psicologicamente é essa a sua posição diante do usurário. (ANDRADE, [193?])

Apesar de acreditar nas inovações das vanguardas, em relação à arte teatral, Oswald de Andrade tem restrições quanto ao teatro de Câmara, alheio às inquietações do povo: "essas experiências intelectualistas são uma degenerescência da própria arte teatral, da própria finalidade do teatro que tem a sua grande linha dos gregos a Goldoni, à comedia dell'Arte, e ao teatro de Moliére e Shakeaspeare" (ANDRADE, 1971, p. 87). Oswald foi grande admirador de Meyerhold "e das fabulosas transformações da cena russa a fim de levar à massa, o espetáculo, a alegria e a ética do espetáculo" (ANDRADE, 1971, p. 87).

Através dessas reflexões sobre a arte teatral, no artigo "Do Teatro, que é Bom..." (ANDRADE, 1971), vemos que a sua concepção está ligada a uma visão do teatro enquanto festa popular e religiosa, rito dionisíaco. $O$ escritor vê a necessidade do teatro participar dos "debates do homem" de sua época, de ser uma instância crítica e transformadora da realidade. Avalio que essa concepção está materializada em sua dramaturgia; $O$ rei da vela realiza as intenções de seu autor quanto à arte teatral, expressas também em seus manifestos. Se pensarmos a Antropofagia enquanto carnavalização, no sentido empregado por Bakhtin (1987), veremos que a transmutação do tabu em totem se dá na profanação, na carnavalização, no rebaixamento do que antes era elevado, reverenciado por medo ou admiração. Para Oswald, a transformação do tabu em totem significava também outro desafio: o tabu seria a experiência trágica do homem, a dor no sentido mais amplo, as interrogações mais profundas da espécie humana que o artista - o artista antropófago - teria que encarar e transformar em totem, em obra de arte materializada e possuidora de vida própria.

Como diz Décio de Almeida Prado (1985, p. 222), Oswald era:

Burguês e anti-burguês ao mesmo tempo. Burguês por nunca ter desertado de sua classe, por correr atrás do dinheiro através de negócios complicadíssimos, por acercar-se pressurosamente das autoridades e das fontes de capital - e tudo isso se encontra transposto grotescamente em $O$ rei da vela. Anti-burguês na medida em que atacava a burguesia por dentro, nas suas maneiras de viver, nos seus hábitos mentais. 
Nesse segundo sentido da "transformação permanente do tabu em totem", O rei da vela é antropofágico porque Oswald a escreveu a partir dos seus próprios tabus.

O rei da vela é um texto de estética antropofágica: não se filia a nenhum estilo ou escola artística em particular, mas serve-se de todas que lhe interessam. "Nunca fomos catequizados, fizemos foi carnaval" diz o Manifesto (ANDRADE, 1928). O "carnaval" aparece nos trocadilhos, enquanto forma de carnavalização da palavra através do chiste, teorizado por Freud (1995), e até na carnavalização da própria literatura, com a parodização do mito de Abelardo e Heloísa. O inconsciente sem censura que aflora na linguagem das personagens da peça ecoa o aforismo que enuncia: "nunca admitimos o nascimento da lógica entre nós". É o elemento irracionalista e primitivista da Antropofagia manifesta no expressionismo da linguagem de $O$ rei da vela. A demonstração da nossa dependência ao Imperialismo, a dependência de Abelardo ao Americano, assim se expressa no Manifesto Antropófago: "A nossa independência ainda não foi proclamada" (ANDRADE, 1928, p. 6). Um aforismo do Manifesto Antropófago sintetiza o que Oswald tratou de expor em sua peça: "a baixa Antropofagia aglomerada nos pecados do catecismo - a inveja, a usura, a calúnia, o assassinato. Peste dos chamados povos cultos e cristianizados, é contra ela que estamos agindo. Antropófagos." Em minha visão, o selvagem é o diferente radical do domesticado, o ameríndio é o diferente radical do europeu, assim como o antropófago é o diferente radical do capitalista canibal.

Como lembrou Haroldo de Campos (2005), "a peça é uma espécie de conotador estrutural do roteiro ideológico percorrido pelo autor e por ele proposto à reflexão crítica do público". Ou ainda, como declarou Décio de Almeida Prado (1985, p. 16), "raios emitidos há tanto tempo e por espaço tão breve (a antropofagia não chegou a durar três anos, não resistindo ao impacto conjunto da crise econômica e da troca de casais), continuam a iluminar o caminho para o teatro mais avançado que se faz hoje no Brasil." Nem todas as obras de Oswald são antropofágicas. A peça $O$ rei da vela, por todo o exposto neste artigo, é antropofágica desde o processo de criação até a sua finalização, materializada em seu conteúdo, estrutura e estética. O rei da vela tem máxima importância no corpus de sua obra exatamente por encarnar em linguagem teatral um brilhante espelhamento, ao revés, em negativo, de seu Manifesto Antropófago. 


\section{Referências bibliográficas}

ANDRADE, O. de. Manifesto antropófago. Revista de Antropofagia, São Paulo, ano 1, n. 1, p. 6-7, 1928.

ANDRADE, O. Manifesto da poesia pau-brasil. Correio da Manhã, 18 de março de 1924.

ANDRADE, O. Estética e política. São Paulo: Globo, 1991.

ANDRADE, O. 0 rei da vela. São Paulo: Globo, 2005.

ANDRADE, O. Obras Completas. Rio de Janeiro: Civilização Brasileira, 1973. Teatro, v. 7 ANDRADE, O. Sobre "O rei da vela". Rio de Janeiro, [193?]. (manuscrito), doc. no 1251, cx. 8, Série Produção Intelectual, Sub-série: Teatro, Arquivo CEDAE UNICAMP. ANDRADE, O. Do teatro que é bom. In: ANDRADE, O. de. Ponta de lança. Rio de Janeiro: Civilização Brasileira, 1971.

ANDRADE, O; GALVÃO, P. Jornal O homem do povo. Março / abril de 1931. São Paulo: Globo, 2009.

ANDRADE FILHO, O. de. Dia seguinte e outros dias. São Paulo: Codex, 2004.

BAKHTIN, M. A cultura popular na Idade Média e no Renascimento. São Paulo: Hucitec, 1987.

CAMPOS, H. de. [Orelha]. In: ANDRADE, O de. O rei da vela, São Paulo: Ed. Globo, 2005.

CHAMIE, M. A vela do pan-sexualismo. In: CHAMIE, M. A linguagem virtual. São Paulo: Quiron, 1976.

FREUD, S. Os chistes e sua relação com o inconsciente. In: FREUD, S. Obras completas de Sigmund Freud: edição standard brasileira. Rio de Janeiro: Imago, 1995.. v. 8.

GEORGE, D. O rei da vela. In: GEORGE, D. Teatro e antropofagia. São Paulo: Global, 1985. p. 41.

MAGALDI, S. Teatro: marco zero. In: ANDRADE, O. de. O rei da vela. São Paulo: Difusão Européia do Livro, 1967. p. 7-27.

MAGALDI, S. Teatro da ruptura: Oswald de Andrade. São Paulo: Global, 2004.

PRADO, D. de A. Prefácio. In: GEORGE, D. Teatro e antropofagia. São Paulo: Global, 1985.

PRADO, D. Exercício findo. São Paulo: Perspectiva, 1987.

VIVEIROS DE CASTRO, E. O que temos nós com isso? In: AZEVEDO, B. Antropofagia palimpsesto selvagem. São Paulo: Cosac Naify, 2016. p. 10-19.

Recebido em 13/04/2019

Aprovado em 12/06/2019

Publicado em 30/08/2019 